\title{
民族間における薬物動態の比較 一健常人を対象とした薬物動態試験デー夕を用いて一
}

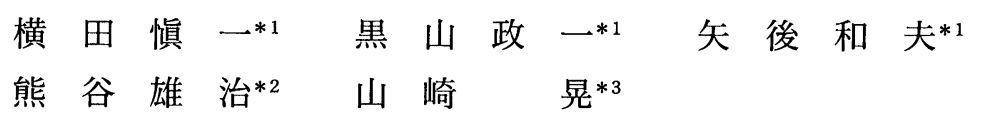

\section{【目的】}

民族間における薬物動態の比較は、医薬品の臨 床開発における重要な課題の一つである。民族 間で薬物動態に相違を生じる要因には、遺伝的 要因、環境・文化的要因などが含まれる。しか し、現在まで民族間における薬物動態の相違に 関する報告は少なく、いくつかの薬物において 代謝酵素の遺伝多型に基づく報告があるのみで ある。また、民族間での薬物動態学的パラメー 夕の比や差を求めた報告も少なく、それらの比 や差が一般的に大きいものであるか否かを判断 する指標はない。そこで、本研究では医薬品の 薬物動態に関する日本と米国、欧州との相違が どの程度のものであるかその全体的な傾向を把 握することを目的に、既に実施された健常人を 対象とした薬物動態試験のパラメータ（最高血 中濃度 : Cmax、血中濃度時間曲線下面積 : AUC）を基に比較検討した。

又、この比較で最も大きな相違が見られた HT-01(仮称)における薬物動態の個人データを 用いた比較検討を行った。

\footnotetext{
*1 北里大学東病院薬剤部 于 228-8520 相模原市麻溝台 2-1-1

*2 北里大学東病院治験管理センター

*3 ブリストル・マイヤーズ スクイブ株式会社
}

\section{【方法】}

薬物動態において、代謝酵素の遺伝多型に基づ く人種差が報告されていない循環器官用薬、抗 生物質など 131 品目を対象として、健常成人

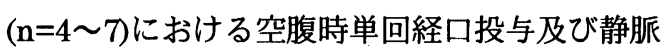
内投与時の薬物動態試験結果を収集した。文献 （資料）収集は、MEDLINE,JMEDICINE に よる検索及び各製薬企業へ依頼することにより 行った。収集した文献に関して、対象者、投与 方法、投与量、測定対象 (未変化体)、測定方 法などから比較の可否を判断した。比較可能と 判断された薬物に関して、その物性、薬物動態 学的特徴などより分類すると共に、日本、米国、 欧州における $\mathrm{Cmax}$ AUC の平均值を用いて、 日本を分子に米国、欧州を分母としてその比を 算出した。日本及び米国での個人毎データより 薬物動態学的パラメータを WIN NONLIN に て算出し、さらに比及び差の信頼区間を比較検 討した。

\section{【結果】}

収集した文献 786 報のうち、214 報が比較可 能と判断された。比較可能と判断された薬物は 74 品目（経口投与 : 47 品目、静注投与 : 27 品目）であった。日本と米国、日本と欧州の比 較において、各パラメータの比の分布に大きな 
相違はなかった。いずれのパラメータの比も、 経口投与で 0.5 から 2、静注投与で 0.6 から 1.6 の範囲内に分布していた。(Fig.1)

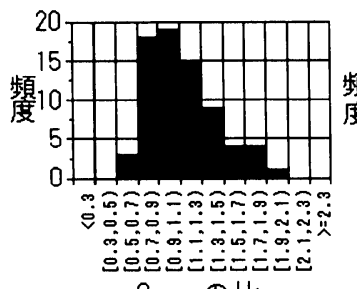
Cmaxの比

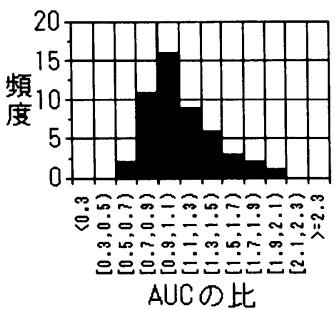

Fig1. 経口投与時の蔯物動態学的パラメータの比 縦軸 : 頻度、横軸 : バラメー夕の比

経口投与における脂溶性、肝代謝型の薬物は Cmax、AUC の比が高い傾向がみられた。

(Fig.2,3)
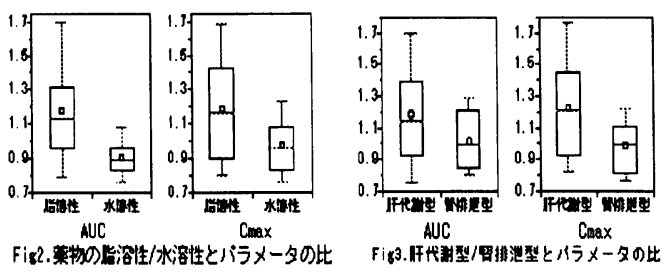

HT-01 のパラメータの比及び差の $90 \%$ 信頼区 間を table1に示す。

Table1.日本及び米国におけるHT-01(仮称)投与の比較

\begin{tabular}{|c|c|c|c|}
\hline $11^{0} 5 x-3$ & 国 & 平均值 \pm SD & 90\%信頼区間 \\
\hline Cmax/Dose & 目本 & $37.5 \pm 8.6$ & \begin{tabular}{l|l} 
& $1.5 \sim 3$ \\
\end{tabular} \\
\hline$(\mathrm{ng} / \mathrm{mL})$ & 来国 & $18.1 \pm 8.3$ & $6.6 \sim 23$ \\
\hline $\begin{array}{c}\text { AUC/Dose } \\
(\mathrm{ng} \cdot \mathrm{hr} / \mathrm{mL})\end{array}$ & \begin{tabular}{|l|l|} 
澘国 \\
\end{tabular} & 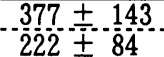 & $1.3 \sim 2.3$ \\
\hline $\operatorname{Tmax}$ & 县本 & $0.9 \pm 0.3$ & $0.4 \sim 0.8$ \\
\hline$(\mathrm{hr})$ & 篓茴 & 1.8 & $-1.5 \sim$ \\
\hline $\mathrm{T} 1 / 2$ & 星本 & & 毞 \\
\hline MRT & 禁本 & $16 \pm \frac{6}{16}+\frac{6}{7}$ & $0.8 \sim 1=$ \\
\hline & & & \\
\hline
\end{tabular}

\section{【考察】}

今回の研究において得られた各薬物における Cmax、AUC の日本と海外の比は 0.5 から 2 の範囲で対数正規分布を示した。これは、安原 らの報告（Cmax、AUC の比 2 以下が全体の $86 \% 、 2$ 以上には代謝䤉素に遺伝多型の存在 が示唆される薬物を含む） ${ }^{1)}$ と類似した結果で、 今後、日本と海外における薬物動態の比較にお ける一つの指標となるものと思われた。

又、両地域での個人毎の薬物動態学的パラメー 夕を用いて、民族間における薬物動態の比較を、 その比及び差の信頼区間で行うことは、各地域 内の個体間変動を考虑した比較を数値的に行う ことができ、有用であると思われた。 脂溶性、肝代謝型薬物で、Cmax、AUC の比 が大きくなる傾向がみられた。今後、このよう な特徴を有する薬物において、日本、米国、欧 州において薬物動態試験を行う際には、十分な 留意を行う必要があると共に、より詳細な試験 の実施が必要と考えられた。

\section{【文献】}

1 ）安原一、他 : 臨床データの相互受入れにお ける人種差要因一薬物動態に関するレトロスペ クティブ研究一、医薬品規制ハーモナイゼイシ ヨン推進国際研究・有効性部門 (平成 4 年度研 究業績報告） 